\title{
Tibuana
}

Journal of applied Industrial Engineering-University of PGRI Adi Buana

DOI : https://doi.org/10.36456/tibuana.4.01.3180.61-64

$p$-ISSN 2622-2027

$e$-ISSN 2622-2035

\section{Patern of Worker Fatigue for Standing Position of Shopkeeper}

\author{
Gempur Santoso $^{1}$, Prihono $^{2}$ \\ ${ }^{1,2}$ Industrial Engineering Department, Faculty of Industrial Technology \\ University of PGRI Adi Buana Surabaya \\ e-mail : gempursantoso@unipa.ac.id
}

\begin{abstract}
Work fatigue is a health and safety problem that can be a trigger factor for accidents at work. The purpose of this study was to analyze the standing work position with work fatigue on the sales clerk (shop assistant) in the Trade Shop, Sidoarjo. This type of research uses analytic observational research, with a sample size of 21 employees, with the technique of taking through questionnaires and interviews for each employee in September, 2020. The level of fatigue is analyzed using a percentage, with categories: $1-\leq 25$ (Not Tired), $>25-\leq$ 50 (Less Tired), $>50-\leq 75$ (Tired), and $>75$ $\leq 100$ (Very Tired). The results showed that the level of fatigue felt by a sales assistant (shop assistant) with a standing work position was in the "Less Tired" category as many as 15 employees with a percentage of $71 \%$, "A little tired" as many as 6 employees with a percentage of $29 \%$, while for the category "Tired. and Very Tired "not felt by all employees, so the percentage is $0 \%$. Suggestion, for standing position sales assistant, who is still experiencing a bit of fatigue need a brief relaxation, by sitting for a while or leaning back for a while.
\end{abstract}

Key words: standing work position, work fatigue, sales assistant.

\section{INTRODUCTION}

Increasingly, humans are involved in the workforce in the sustainable development process. In order for the workforce to remain healthy and productive at work, the role of Occupational Safety and Health is the main point to implement. This is also supported by the development of the reach of development in all economic sectors, including the informal, traditional and small industry sectors. Sustainable development also has problems, namely the health condition of the workforce.
If the number of jobs at work increases, there will be fatigue at work.

Work fatigue is a health and safety problem that can be a trigger factor for accidents at work. Fatigue due to work is often interpreted as a process of decreasing efficiency, work performance, and reduced physical strength / endurance to continue the activities that must be done (Wignjosoebroto, 2006). Decreased performance in working together means decreased work productivity. If the productivity level of a workforce is disturbed by the effects of physical and psychological fatigue, the resulting impact will also be felt by the company in the form of a decrease in company productivity (Anjar, 2016).

At this time, in general there are still many people who are not familiar with the name ergonomics, so most of them do not pay attention to work performance or work attitude or work position, so they quickly feel fatigue, pain and other health problems in their bodies. One of the factors causing fatigue in industry varies widely, it can be influenced by workload, work shift, work environment, physical problems, and body health conditions can be influenced by individual factors, such as age, sex, diet, health status, nutritional status , and psychological conditions.

A resistance (reaction) to a load (action) causes the muscles to experience excessive contraction (Santoso, 2013). Basically, working in a standing position is more tiring than sitting and the energy spent standing is $10-15 \%$ more than sitting (Tarwaka, 2014). Based on the description above, the author is interested in seeing an analysis of standing work positions with work fatigue in a sales clerk (shop assistant) in a trade shop in Sidoarjo. 


\section{Tibuana}

Journal of applied Industrial Engineering-University of PGRI Adi Buana

DOI : https://doi.org/10.36456/tibuana.4.01.3180.61-64

p-ISSN 2622-2027

$e$-ISSN 2622-2035

\section{RESEARCH METHOD}

\subsection{Type of work}

The work that will be evaluated for fatigue patterns is physical work. In the trade and service industry by evaluating the position / work performance, especially the standing position of a clerk (shop assistant) in a trade shop in Sidoarjo.

\subsection{Subject}

The population of this study were employees (salespeople) of trade shop in Sidoarjo Kota, amounting to 30 employees. Shif clerk works daytime during work 8 hours of standing work position. Obtained a sample of 21 employees, because 9 people were not willing. Data collection techniques through general fatigue questionnaires and interviews for each employee.

\subsection{Types of research}

This type of research uses analytic observational research which is analyzed using percentages, with categories: $1-\leq 25$ (Not Tired), $>25-\leq 50$ (Less tired), $>50-\leq 75$ (Tired), and $>75-\leq 100$ ( Very tired).

\section{ANALYSIS AND DISCUSSION}

Table 1. shows the distribution of respondents based on the fatigue value of a sales clerk (shop assistant) at a trade shop in Sidoarjo Kota in 2020. With the following terms and conditions:

$1-\leq 25$ : Not Tired

$>25-\leq 50$ : Less tired

$>50-\leq 75$ : Tired

$>75-\leq 100$ : Very Tired

Table 1. Distribution of Respondents based on Fatigue Value

\begin{tabular}{ccl}
\hline No & Fatigue Value & Category \\
\hline 1 & 3.33 & Not Tired \\
2 & 13.33 & Not Tired \\
3 & 50.00 & Less tired \\
4 & 6.67 & Not Tired \\
5 & 6.67 & Not Tired \\
6 & 23.33 & Not Tired \\
7 & 26.67 & Less tired \\
8 & 13.33 & Not Tired \\
9 & 13.33 & Not Tired \\
10 & 26.67 & Less tired \\
11 & 13.33 & Not Tired \\
12 & 13.33 & Not Tired \\
13 & 30.00 & Less tired \\
14 & 20.00 & Not Tired \\
15 & 6.07 & Not Tired \\
16 & 13.33 & Not Tired \\
17 & 36.67 & Less tired \\
18 & 30.00 & Less tired \\
19 & 6.67 & Not Tired \\
20 & 13.33 & Not Tired \\
21 & 6.67 & Not Tired \\
\hline
\end{tabular}




\section{Tibuana}

Journal of applied Industrial Engineering-University of PGRI Adi Buana

DOI : https://doi.org/10.36456/tibuana.4.01.3180.61-64

$p$-ISSN 2622-2027

$e$-ISSN 2622-2035

From the data in Table 1 above, the results obtained from the distribution of respondents based on the value of fatigue with each

- $\quad$ Tired

$=-($ Tidak ada $)$

category are as follows:

$$
=0 \%
$$

- Not Tired $=15$

$$
=71.43 \%
$$$$
=71 \%
$$

- Less tired $=6$

$$
=28,57 \%
$$$$
=29 \%
$$

- Very Tired $=-($ Tidak ada $)$

$$
=0 \%
$$

Based on table 1 above, a picture 1 of the following sales assistant labor fatigue pattern is made.

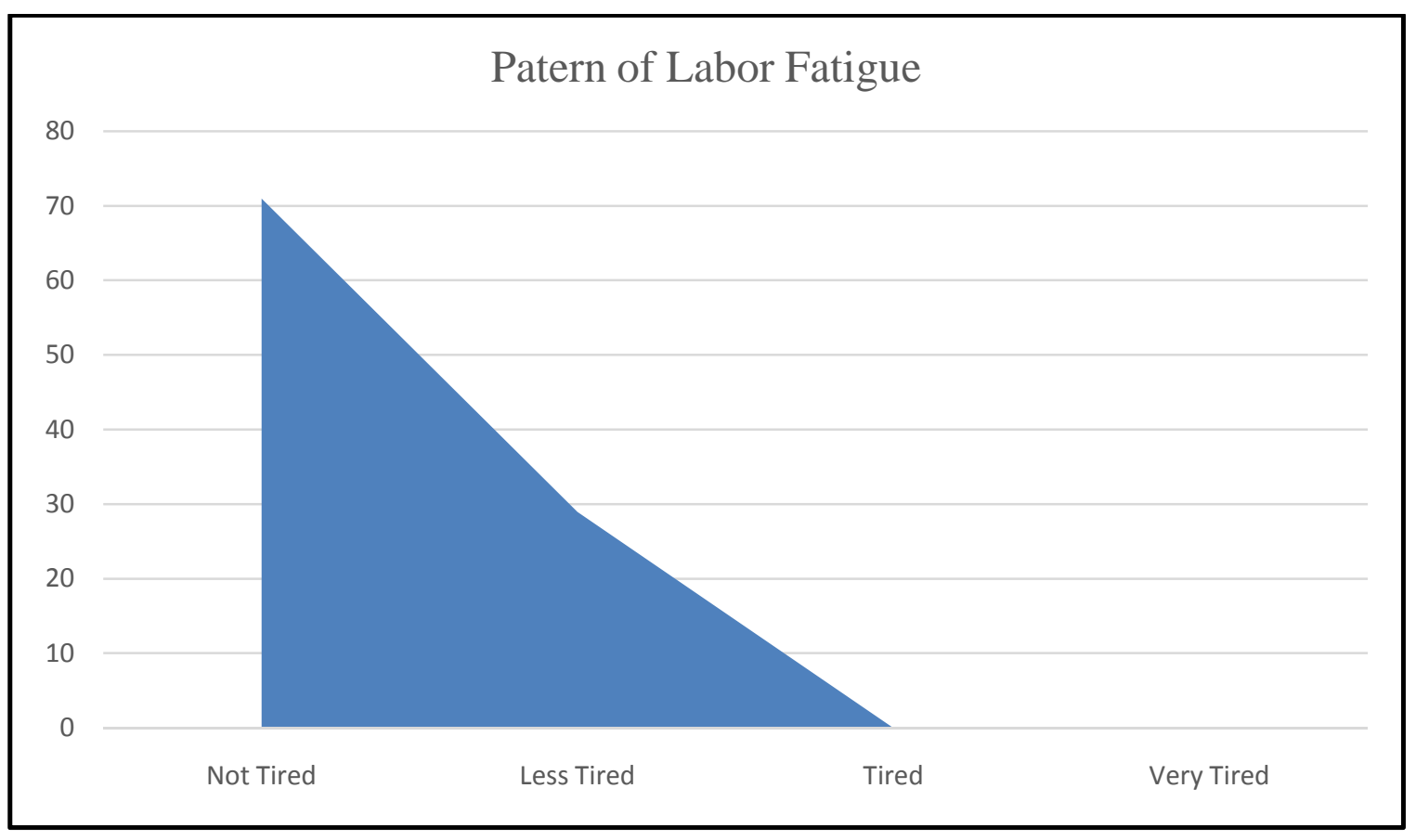

Figure 1. Pattern of Salesperson Labor Fatigue

Distinguishing table 1 and figure 1 above, it can be said that the sales assistant after working in a standing position is not tired and not very tired, but $71 \%$ feel less tired and $29 \%$ feel a little tired.

Why is it that the standing position clerk does not feel tired or very tired. Paying attention to the results of the interview to the sales assistant while working, they stated that "usually the sales assistant if they feel tired will sit for a while in the customer chair, if the chair is used by the customer it will lean on a shirt pole or lean on the wall" (Primary Data,
September 2020). So, in the form of a customer chair, a display of merchandise clothes poles, and a wall, a temporary relaxation tool is required when working in a standing position.

Dian Larasati (2018) "there is a significant relationship between ergonomic standing work and musculoskeletal disorders". This indicates that when working in a standing position, the skeletal muscles are tired.

Then, the fatigue is greater in the back in the spinal muscles (vertebralis) than in the legs. As the results of Siska MA's research 


\section{Tibuana}

Journal of applied Industrial Engineering-University of PGRI Adi Buana

DOI : https://doi.org/10.36456/tibuana.4.01.3180.61-64

$p$-ISSN 2622-2027

$e$-ISSN 2622-2035

(2017) for standing work posture in mechanical welding, it was found that "the risk of being on the back is $70.0 \%$, on the legs $43.3 \%$..." means that working in a standing position has a greater risk of the back than the legs. .

Therefore, that the sales assistant work in a standing position to be able to relax for a while requires customer chairs, clothes poles and walls. Customer chair for short relaxation. Besides relaxing the poles of clothes and walls, it is also to rest briefly for the muscles in the hind limb. In the spine that makes the body erect are the erector muscles. So that after working the standing position for 8 hours it only melted a little.

\section{CONCLUSIONS AND SUGGESTIONS 4.1 Conclusion}

From the results of the research conducted, it was found that the level of fatigue felt by a sales assistant (shop assistant) with a standing work position in a trade shop in Sidoarjo, was in the category of "Less Tired" as many as 15 employees with a percentage of $71 \%$, "A little tired" as many as 6 employees with a percentage $29 \%$, while the category "Tired and Very Tired" was not felt by all employees, so the percentage was $0 \%$. To reduce work fatigue, standing positions need to be in touch for a while, using chairs that can be used by customers, clothes poles, and walls. So, a sales assistant (shop assistant) in working in a standing position feels more "Less Tired" than "A little Tired", and not to the point of feeling "Tired and Very Tired".

\subsection{Suggestion}

Based on the results of the study, it was found that $100 \%$ of the workforce experienced fatigue in the "Less Tired and Somewhat Tired" category, for that it would be better if the workforce made optimal use of the rest time in the form of short relaxation, given a complete relaxation facility, so that the perceived work fatigue was reduced or not. Until it becomes a burden of fatigue.

\section{References}

1. Anjar, 2017,Faktor Yang Berhubungan Dengan Kelelahan Kerja Pada Karyawan Matahari Departement Store Cabang Lippo Plaza Kendari Tahun 2016.Jurnal Ilmiah Mahasiswa Kesehatan Masyarakat. 2 (1).

2. Dian Larasati, Yamtama, Achmad Husen, 2018, Status ergonomic posisi kerja berdiri dengan gangguan otot rangkan (musculoskeletal disorders) pada tenaga kerja laundry di wilayah Condoncatur, Yogyakarta: Respository Poltekesjogja.

3. Siska Maulana Anggrianti, Bina Kurniawan, Baju Widjasena, Hubungan antara postur kerja berdiri dengan keluhan nyeri kaki pada pekrja aktivitas mekanik section welding di PT. X, e-Journal vol 5 Oktober 2017 ISSN: 2356-3346, Semarang: Universitas Diponegoro.

4. Santoso, G., 2013,Manajemen Kelelahan Kerja. Jakarta : Prestasi Pustaka Publisher.

5. Tarwakala, 2014,Ergonomi Industri dasardasar pengetahuan ergonomic dan aplikasi di tempat kerja, Surakarta : Harapan Press.

6. Wignjosoebroto, 2006,Ergonomi Studi Gerak Dan Waktu, Surabaya : Guna Widya. 